\title{
Pyrethroid resistance in southern African Anopheles funestus extends to Likoma Island in Lake Malawi
}

\author{
RH Hunt ${ }^{1,2}$, M Edwardes $^{3}$, M Coetzee $^{1,2^{*}}$
}

\begin{abstract}
Background: A mosquito survey was carried out on the island of Likoma in Lake Malawi with a view to collecting baseline data to determine the feasibility of implementing an integrated malaria vector control programme. No vector control interventions are currently being applied on the island apart from the sporadic use of treated and untreated bed nets.

Results: Large numbers of Anopheles funestus were found resting inside houses. WHO susceptibility tests were carried out on wild caught females and 1-5 day old F-1 female progeny. Wild caught females were tested on deltamethrin ( $77.8 \%$ mortality) and bendiocarb (56.4\% mortality). Female progeny were tested on deltamethrin (41.4\% mortality), permethrin (40.4\%), bendiocarb (52.5\%), propoxur (7.4\%), malathion, fenitrothion, DDT, dieldrin (all 100\%) and pirimiphos-methyl (98.9\%). The malaria parasite rate was 4.9\%. A small number of Anopheles arabiensis were also collected.

Conclusion: This locality is $1,500 \mathrm{~km}$ north of the currently known distribution of pyrethroid resistant An. funestus in southern Africa. The susceptibility results mirror those found in southern Mozambique and South African populations, but are markedly different to An. funestus populations in Uganda, indicating that the Malawi resistance has spread from the south.
\end{abstract}

\section{Background}

Anopheles funestus is the major malaria vector in southern Africa. Early records of its involvement in malaria transmission give Plasmodium falciparum parasite rates as high as $22 \%$ in South Africa [1]. More recently, in Tanzania $11 \%$ infection rate was recorded [2] and 5\% in southern Mozambique [3].

South Africa eradicated An. funestus in the 1950's when an extensive indoor residual spraying (IRS) campaign using DDT was rolled out. In the next 50 years, this vector species was recorded only once during a small malaria outbreak in the northern part of the country [4]. In 1999/ 2000, however, South Africa experienced its worst malaria outbreak since the introduction of IRS in the 1950's and An. funestus was found once again in northern KwaZulu/ Natal, just south of Mozambique [5,6]. The P. falciparum

\footnotetext{
* Correspondence: maureenc@nicd.ac.za

'Malaria Entomology Research Unit, School of Pathology, Faculty of Health Sciences, University of the Witwatersrand, Johannesburg, South Africa Full list of author information is available at the end of the article
}

parasite rate in An. funestus was $5.4 \%$ and the mosquitoes were found to be resistant to both pyrethroids and carbamates.

Subsequent research in southern Mozambique showed that the insecticide resistant population of An. funestus extended north of the capital, Maputo [7-9]. Most recently, resistance was found in An. funestus from Chokwe [10], approximately $200 \mathrm{~km}$ north of the capital, where previously this population was found to be susceptible [8].

The present study provides evidence of insecticide resistance in An. funestus from an island in Lake Malawi that is considerably further north than any previous records of resistance.

\section{Materials and methods Study site}

The mosquito survey was carried out on Likoma Island in Lake Malawi $\left(12^{\circ} 04^{\prime} \mathrm{S}, 34^{\circ} 44^{\prime} \mathrm{E}\right)$ from 10 - 14 May 2010 (Figure 1). The island is a series of outcrops and
C Biomed Central

(c) 2010 Hunt et al; licensee BioMed Central Ltd. This is an Open Access article distributed under the terms of the Creative Commons Attribution License (http://creativecommons.org/licenses/by/2.0), which permits unrestricted use, distribution, and reproduction in any medium, provided the original work is properly cited. 


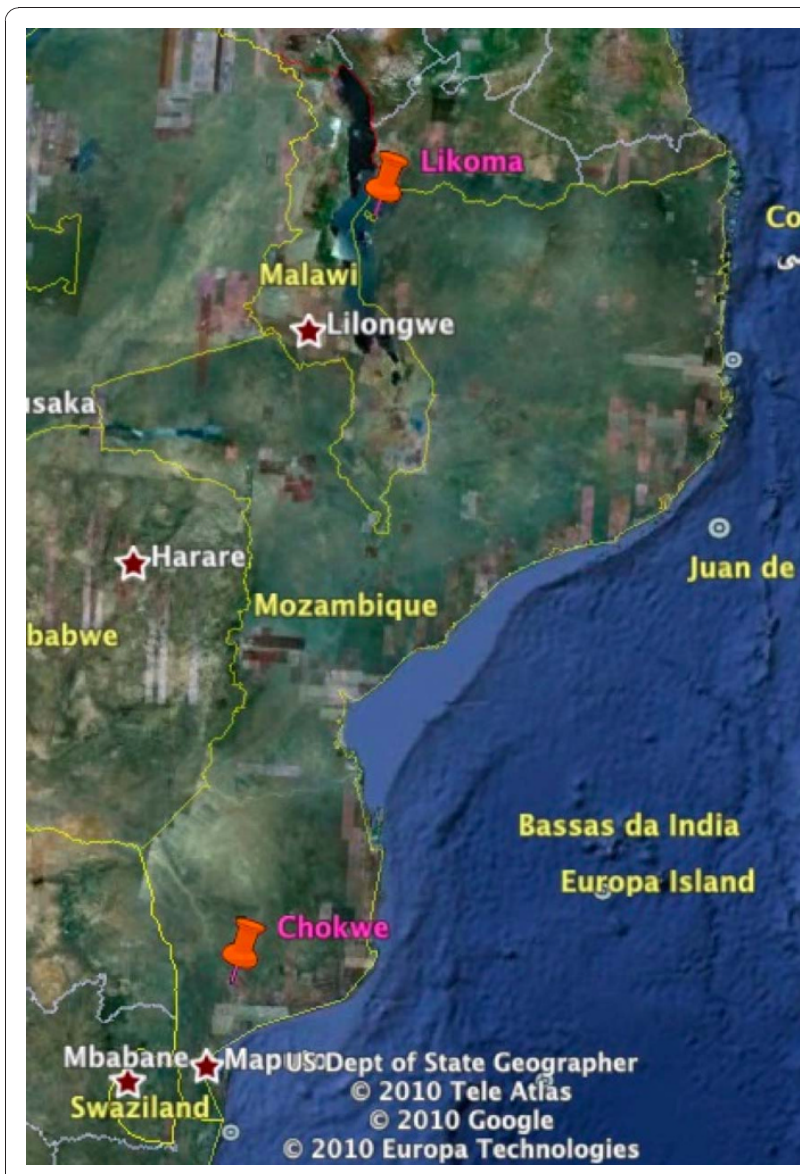

Figure 1 Map of Malawi and Mozambique showing Likoma island in the north and the currently known limit of pyrethroid resistant An. funestus at Chokwe in the south of Mozambique [10], approximately $1,500 \mathrm{~km}$ apart.

the housing on the island consists mainly of scattered homesteads with residents engaged in fishing and smallscale subsistence farming. Many houses were searched for mosquitoes mostly without success, but a substantial An. funestus population was found in a few houses close to a small area being used for rice cultivation.

\section{Mosquito collections}

Mosquitoes were collected resting inside houses using a hand aspirator. Some samples were used immediately for WHO susceptibility tests while others were packaged and returned to Johannesburg where egg batches were obtained and larvae reared through to F-1 adults.

\section{Laboratory processing}

Species identification was carried out using the methods of Koekemoer et al. [11] for the An. funestus group and Scott et al. [12] for the An. gambiae complex.

Wild females were screened for malaria parasite infection using ELISA [13].
Table 1 Insecticide susceptibility tests carried out on An. funestus females on Likoma Island

\begin{tabular}{ccccc}
\hline & Total & $\begin{array}{c}\text { No. } \\
\text { dead }\end{array}$ & $\begin{array}{c}\text { No. } \\
\text { alive }\end{array}$ & $\begin{array}{c}\text { \% Mortality } \\
\text { 24-hr post- } \\
\text { exposure }\end{array}$ \\
\hline $\begin{array}{c}0.05 \% \\
\text { Deltamethrin }\end{array}$ & 53 & 42 & 11 & 79.2 \\
\hline $0.1 \%$ Bendiocarb & 27 & 16 & 11 & 59.2 \\
\hline Control & 31 & 2 & 29 & 6.5 \\
\hline
\end{tabular}

Insecticide susceptibility tests were carried out using the WHO [14] standard test kits and treated papers from the WHO Collaborating Centre in Penang, Malaysia. The insecticides tested and their discriminating doses are given in Table 1 and 2.

\section{Results}

One hundred and eleven wild An. funestus females of unknown age were tested for insecticide resistance under field conditions with no temperature or humidity control. A total of 6 An. gambiae complex females and over 120 females and \pm plusorminus 90 males of $A n$. funestus, together with a small collection of An. gambiae larvae, were packaged and transported back to the laboratory in Johannesburg.

A total of 223 An. funestus were subjected to molecular assays including all the wild adults used in the susceptibility tests $(\mathrm{n}=111)$ as well as the live females brought back to the laboratory for egg laying $(\mathrm{n}=112)$. 97.3\% were successfully identified as An. funestus s.s. (five specimens did not amplify a PCR product and one specimen was identified as An. funestus-like). All males and females of the An. gambiae complex (wild adults and adults reared from larvae, $\mathrm{n}=89$ ) were identified as An. arabiensis.

Table 2 Insecticide susceptibility tests carried out on 1$\mathbf{5}$ day old female progeny of An. funestus from Likoma Island

\begin{tabular}{ccccc}
\hline & Total & No. dead & No. alive & \% Mortality \\
\hline 0.05\% Deltamethrin & 174 & 72 & 102 & 41.4 \\
\hline 0.75\% Permethrin & 146 & 59 & 87 & 40.4 \\
\hline 0.1\% Bendiocarb & 141 & 74 & 67 & 52.5 \\
\hline 0.1\% Propoxur & 54 & 4 & 50 & 7.4 \\
\hline 5\% Malathion & 126 & 126 & 0 & 100 \\
\hline 1\% Fenitrothion & 103 & 103 & 0 & 100 \\
\hline 0.9\% Pirimiphos methyl & 99 & 98 & 1 & 98.9 \\
\hline 4\% DDT & 155 & 155 & 0 & 100 \\
\hline 4\% Dieldrin & 137 & 137 & 0 & 100 \\
\hline Controls & 137 & 0 & 137 & 0 \\
\hline
\end{tabular}


Of the 81 wild An. funestus females tested for parasite infection, $4.9 \%$ were positive for $P$. falciparum using the ELISA method.

The results of the first insecticide susceptibility tests, carried out on the island using wild female An. funestus of unknown age, are given in Table 1. Since the controls gave $>5 \%$ mortality, Abbott's formula [14] was used to correct the results, giving $77.8 \%$ mortality on deltamethrin and $56.4 \%$ on bendiocarb. The papers used in the field were tested in the laboratory using a susceptible An. gambiae colony and gave $100 \%$ mortality for all samples and replicates $(\mathrm{n}=100$ for each insecticide).

The second round of insecticide susceptibility tests was carried out in the laboratory at $25^{\circ} \mathrm{C}$ and $85 \% \mathrm{RH}$ using 1-5 day old An. funestus females pooled from approximately 120 egg batches. Nine different insecticides from all four classes were tested and the results are given in Table 2 .

Unfortunately, the An. arabiensis sample reared from larvae was too small ( $\mathrm{n}=42$ females) to carry out meaningful susceptibility tests.

\section{Discussion}

The marked difference between the deltamethrin susceptibility tests carried out on wild females in the field and those on the laboratory reared, 1-5 day old F-1 progeny $(\mathrm{p}<0.005)$, can be explained in two ways. One, high temperatures are known to affect the survival of mosquitoes exposed to insecticides [15] and this may account for the high mortality in the field samples. Two, An. funestus susceptibility to this sub-class of pyrethroids may be age dependent [16]. Since the survey was carried out in May towards the end of the transmission season, it is likely that the wild-caught females tested in the field were an aging population and were therefore more susceptible to the insecticides. However, Hunt et al. [16] also report that blood fed, mated, females did not show any decrease in resistance over time, and aging wild populations would all be mated and have taken numerous blood meals.

It is clear from the susceptibility results that a resistance management strategy will have to be devised and implemented in order to control malaria on the island. If pyrethroid treated bed nets are to be distributed widely on Likoma Island, then IRS must be carried out simultaneously with an organophosphate or DDT in order to manage the resistance. Carbamates are unfortunately not an option with such a high frequency of survival. The An. funestus population is fully susceptible to DDT, which raises the possibility of using DDT for IRS perhaps in a rotation with one of the organophosphates.

There is already extensive use of bed nets on the island with an assortment of treated and untreated nets, old and new, damaged and intact. There is also obvious variation in usage. Frequently, nets were present in the house but not being used. If a combination of bed nets and IRS is under consideration, an important component of such a strategy must be education and monitoring of net use. When the mosquito populations decrease, either due to seasonal change or in response to control measures, many people will stop using the nets. It is also a reality that in a community where livelihood depends on fishing, some nets will be used for this purpose (Figure 2).

The most worrying aspect of this survey is the discovery of pyrethroid and carbamate resistance in the $A n$. funestus population approximately $1,500 \mathrm{~km}$ north (Figure 1) of its current known distribution at Chokwe in southern Mozambique [10]. The report by Casimiro et al. [9] on samples collected from central Mozambique in 2006 showed that An. funestus had $>95 \%$ mortality to pyrethroids and carbamates. The WHO criteria recommend that this percentage of susceptibility requires further investigation, but operationally it is unlikely that a control programme would change its policy based on this frequency of resistance/susceptibility.

Likoma Island in Lake Malawi is just a few kilometres away from Mozambique and presumably the mosquitoes are either blown over by the wind or brought on boats that ply their trade between the island and the mainland. One must assume, therefore, that the An. funestus population in northern Mozambique is also resistant and this has serious implications for current malaria control efforts being undertaken in this region. Since both pyrethroid and carbamate resistance has been found in the Likoma population, mirroring the resistance found in more southerly populations, it can be assumed that the resistance is spreading northwards through the An. funestus populations through gene flow,

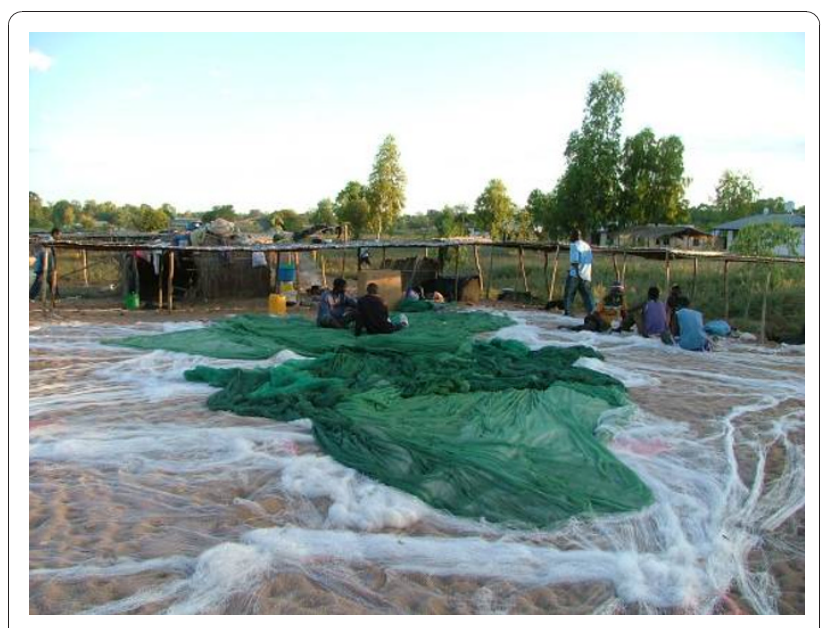

Figure 2 Fishermen on Likoma drying their nets. The green nets are bed nets that have been modified for fishing. 
and not arising as separate genetic mutation events. There are no obvious geographical barriers to gene flow in this region of southern Africa and presumably we can expect the resistance to spread northwards into southern Tanzania and westwards into Zambia and Zimbabwe. The recently reported resistance in An. funestus from Uganda [17] is obviously different to that observed in southern African populations, based on both susceptibility tests and molecular characterization of the P450 genes $[5,16,18,19]$. In Uganda, both pyrethroid and DDT resistance was found, with full susceptibility to carbamates, suggesting that this resistance has arisen independently under different selection pressures as suggested by Morgan et al. [10] based on their molecular data.

This paper highlights the seriousness of the rapid spread of insecticide resistance in An. funestus in southern Africa and the urgent need for resistance management strategies within malaria vector control programmes within the region.

\section{Acknowledgements}

Mr John Chiphwanya and Mrs Doreen Ali of the Malawi National Malaria Control Programme are thanked for support for this project and for assistance with the logistics. Staff and students of the Vector Control Reference Unit are thanked for technical support in the field and the laboratory. The survey was funded by Bayer and the DST/NRF Research Chair grant to MC

\section{Author details}

'Malaria Entomology Research Unit, School of Pathology, Faculty of Health Sciences, University of the Witwatersrand, Johannesburg, South Africa. ${ }^{2}$ Vector Control Reference Unit, National Institute for Communicable Diseases of the National Health Laboratory Service, Private Bag X4, Sandringham 2131, South Africa. ${ }^{3}$ Bayer Environmental Science, P.O. Box 143 Isando, 1600, South Africa.

\section{Authors' contributions}

All authors had input into the conception of the project, data analysis and drafting of the manuscript.

\section{Competing interests}

The authors declare that they have no competing interests.

Received: 14 October 2010 Accepted: 31 December 2010 Published: 31 December 2010

\section{References}

1. Gillies MT, De Meillon B: The Anophelinae of Africa South of the Sahara. Publication of the South African Institute for Medical Research, Johannesburg; 196854.

2. Shiff CJ, Minjas JN, Hall T, Hunt RH, Lyimo S, Davis RJ: Malaria infection potential of anopheline mosquitoes sampled by light trapping indoors in coastal Tanzanian villages. Med Vet Entomol 1995, 9:256-262

3. Aranda C, Aponte JJ, Saute F, Asimiro S, Pinto J, Sousa C, Rosario V, Petrarca V, Dgedge M, Alonso P: Entomological characteristics of malaria transmission in Manhica, a rural area in southern Mozambique. J Med Entomol 2005, 42:180-186.

4. De Meillon B, Van Eeden G, Coetzee L, Coetzee M, Meiswinkel R, Du Toit C, Hansford C: Observations on a species of the Anopheles funestus subgroup, a suspected exophilic vector of malaria parasites in northeastern Transvaal, South Africa. Mosa News 1977, 37:657-661.

5. Hargreaves K, Koekemoer LL, Brooke BD, Hunt RH, Mthembu J, Coetzee M: Anopheles funestus is resistant to pyrethroid insecticides in South Africa. Med Vet Entomol 2000, 14:181-189.
6. Coetzee M: Malaria and dengue vector biology and control in southern and eastern Africa. In Bridging Laboratory and Field Research for Genetic Control of Disease Vectors. Volume Chapter 9. Edited by: Knols BGJ, Louis C. Wageningen UR Frontis Series \#11; 2006:101-109.

7. Brooke BD, Kloke G, Hunt RH, Temu EA, Koekemoer LL, Taylor ME, Coetzee M: Bioassay and biochemical analyses of insecticide resistance in southern African Anopheles funestus. Bull Entomol Res 2001, 91:265-272.

8. Casimiro S, Coleman M, Mohloai P, Hemingway J, Sharp B: Insecticide resistance in Anopheles funestus (Diptera: Culicidae) from Mozambique. J Med Entomol 2006, 43:267-275.

9. Casimiro S, Hemmingway J, Sharp BL, Coleman M: Monitoring the Operational Impact of Insecticide Usage for Malaria Control on Anopheles funestus from Mozambique. Mal J 2007, 6:142.

10. Cuamba N, Morgan JC, Irving H, Steven A, Wondji CS: High level of pyrethroid resistance in an Anopheles funestus population of the Chokwe District in Mozambique. PLoS ONE 2010, 5(6):e11010.

11. Koekemoer LL, Kamau L, Hunt RH, Coetzee M: A cocktail polymerase chain reaction assay to identify members of the Anopheles funestus (Diptera: Culicidae) group. Am J Trop Med Hyg 2002, 66:804-811.

12. Scott JA, Brogdon WG, Collins FH: Identification of single specimens of the Anopheles gambiae complex by the polymerase chain reaction. Am J Trop Med Hyg 1993, 49:520-529.

13. Wirtz RA, Zavala F, Charoenvit Y, Campbell GH, Burkot TR, Schneider I, Esser KM, Beaudoin RL, Andre RG: Comparative testing of Plasmodium falciparum sporozoite monoclonal antibodies for ELISA development. Bull WId Hith Org 1987, 65:39-45.

14. World Health Organization: Test procedures for Insecticide Resistance Monitoring in Malaria Vectors, Bio-Efficacy and Persistence of Insecticides on Treated Surfaces. Geneva, Switzerland 1998, Unpublished doc WHO/CDS/CPC/MAL/98.12.

15. Ramsdale $C D$, Herath $P R$, Davidson G: Recent developments of insecticide resistance in some Turkish anophelines. J Trop Med Hyg 1980, 83:11-19.

16. Hunt RH, Brooke BD, Pillay C, Koekemoer LL, Coetzee M: Laboratory selection for and characteristics of pyrethroid resistance in the malaria vector Anopheles funestus. Med Vet Entomol 2005, 19:271-275.

17. Morgan JC, Irving H, Okedi LM, Steven A, Wondji CS: Pyrethroid resistance in an Anopheles funestus population from Uganda. PLOS ONE 2010, 5(7): e11872.

18. Amenya DA, Koekemoer LL, Vaughan A, Morgan JC, Brooke BD, Hunt RH, Ranson H, Hemingway J, Coetzee M: Isolation and sequence analysis of P450 genes from a pyrethroid resistant colony of the major malaria vector Anopheles funestus. DNA Sequence 2005, 16:437-445.

19. Wondji CS, Irving H, Morgan J, Lobo N, Collins FH, Hunt RH, Coetzee M, Hemingway J, Ranson H: Two duplicated P450 genes are associated with pyrethroid resistance in Anopheles funestus, a major malaria vector. Gen Res 2009, 19:452-459.

doi:10.1186/1756-3305-3-122

Cite this article as: Hunt et al:: Pyrethroid resistance in southern African Anopheles funestus extends to Likoma Island in Lake Malawi. Parasites \& Vectors 2010 3:122.

\section{Submit your next manuscript to BioMed Central and take full advantage of:}

- Convenient online submission

- Thorough peer review

- No space constraints or color figure charges

- Immediate publication on acceptance

- Inclusion in PubMed, CAS, Scopus and Google Scholar

- Research which is freely available for redistribution

Submit your manuscript at www.biomedcentral.com/submit
C Biomed Central 